\title{
INHIBITION BY AMOEBA-SPECIFIC ANTISERUM AND BY CYTOCHALASIN B OF THE \\ CYTOPATHOGENICITY OF NAEGLERIA FOWLERI IN MOUSE EMBRYO-CELL CULTURES
}

\author{
T. BROWN \\ Department of Bacteriology, University of Aberdeen, \\ Foresterhill, Aberdeen $A B 92 Z D$ \\ Plate XXIII
}

NAEGLERIA FOWLERI, the causative agent of acute primary meningoencephalitis, has been described as one of the most lethal of micro-organisms (Phillips, 1974). In man and in experimentally infected laboratory animals, amoebae proliferate rapidly and cause extensive destruction of the olfactory and brain tissues (Carter, 1968, 1970, 1972; Duma, 1972). In cell cultures too, amoebae exhibit a pronounced cytopathic activity that is thought to correlate with pathogenicity in vivo (Culbertson, 1971; Newton, 1972; Chang, 1973). Secondary mouse-embryo (ME) cells were recently shown to provide a sensitive in-vitro host system for the study of mechanisms of naegleria-induced mammalian-cell damage by techniques that are precluded in the intact animal (Brown, 1978). Observations of trophozoite behaviour in these cultures suggested that amoebae destroy mammalian cells only while in direct contact with them, rather than by secreting cytotoxic or cytolytic substances into the culture medium. While revealing some evidence for phagocytic activity by trophozoites, these studies did not exclude the possibility that amoebae possess membrane-associated cytotoxic enzymes that are activated by contact with a susceptible host cell and participate in its destruction. Eaton, Meerovitch and Costerton $(1969,1970)$ have proposed such a mechanism for the in-vitro cytopathogenicity of Entamoeba histolytica, which also appears to kill cells on contact (Jarumilinta and Kradolfer, 1964), and certain features of tissue damage by $N$. fowleri in mice have likewise been interpreted in terms of enzyme-mediated cytolysis (Martinez et al., 1973; Maitra et al., 1974, 1976; Visvesvara and Callaway, 1974). It was decided, therefore, to investigate the possible existence of amoeba-associated cytotoxins by observing whether the cytopathogenicity of Naegleria in ME-cell cultures could still be expressed in the presence of non-lethal inhibitors of trophozoite motility and phagocytosis.

\section{MATERIALS AND METHODS}

Cultures. Procedures for the maintenance of $N$. fowleri strain HB-1 in axenic culture, the

Received 21 Dec. 1978; accepted 28 Jan. 1979. 
processing of trophozoites for inoculation on to mammalian-cell monolayers and the preparation of secondary ME-cell cultures and associated media were as reported previously (Brown, 1978). Monolayers were established in $100 \times 12-\mathrm{mm}$ tissue-culture tubes and, for photomicrography, in disposable tissue-culture chambers (Sterilin Ltd, Richmond, Surrey; see Brown, 1978).

Antiserum preparation. Procedures were based on those described by Anderson and Jamieson (1972). Trophozoites from three-day axenic cultures were washed by centrifugation at $200 \mathrm{~g}$ for $10 \mathrm{~min}$. in three changes of amoeba saline (Page, 1967) and suspended at a concentration of $1 \times 10^{6} / \mathrm{ml}$ in $0.85 \%$ saline solution containing $0.1 \%$ of formalin. The suspensions were stored at $4^{\circ} \mathrm{C}$ for up to 18 days while awaiting inoculation into animals.

New Zealand White rabbits $(3-4 \mathrm{~kg})$ were inoculated intravenously on days $0,3,7,12$, and 18 with, respectively, $0.5 \mathrm{ml}, 0.5 \mathrm{ml}, 1.0 \mathrm{ml}, 2.0 \mathrm{ml}$ and $1.0 \mathrm{ml}$ of warmed $\left(37^{\circ} \mathrm{C}\right)$ formolised amoeba suspensions. Sera from pre-inoculation and post-inoculation bleeds, collected on days 0,24 and 34 , were stored in $2 \cdot 0-\mathrm{ml}$ volumes at $-20^{\circ} \mathrm{C}$.

Antiserum assay. Naegleria strain HB-1 antiserum titres were determined by immobilisation (TI) and agglutination (TA) tests in which the antigens were, respectively, living trophozortes suspended in ME-cell maintenance medium (MM) and formolised amoebae at a concentration of 1-2 $\times 10^{6} / \mathrm{ml}$ (Singh and Das, 1970; Anderson and Jamieson, 1972); 0.1 ml of the appropriate antigen was added to $0.1 \mathrm{ml}$ of doubling dilutions of non-inactivated sera in amoeba saline (TA tests) or ME-cell MM (TI tests), prepared in the wells of disposable flat-bottomed tissue-culture trays (Linbro; Gibco-Biocult Ltd, Paisley, Scotland). The wells were sealed with adhesive covers and the plates were incubated at $37^{\circ} \mathrm{C}$ for $2 \mathrm{~h}$. Normal (non-immune) rabbit serum and diluent controls were included in each test and the results were read with a Nikon stereo-microscope. Antiserum titres by TA and TI tests, recorded as the highest final dilutions causing complete trophozoite agglutination or complete inhibition of translational movement, were 512 and 32 respectively. Normal rabbit serum at a minimum dilution of 1 in 4 failed to agglutinate or immobilise amoebae.

Inhibition of naegleria cytopathogenicity by specific antiserum. Washed trophozoites were suspended at a concentration of $10^{5}$ or $10^{4} / \mathrm{ml}$ in ME-cell MM containing four immobilising units $(4 \times \mathrm{TI}$ titre) of $N$. fowleri-specific rabbit antiserum. Normal rabbit serum was used in controls and the amoeba-serum mixtures were held at room temperature $\left(c .22^{\circ} \mathrm{C}\right)$ for $30 \mathrm{~min}$., then inoculated in $1.0-\mathrm{ml}$ volumes into duplicate culture tubes containing confluent ME-cell monolayers. The tubes were incubated for up to 7 days at $37^{\circ} \mathrm{C}$ and inspected daily for the appearance of cytopathic effect (CPE).

Cytochalasin B (Aldrich Chemical Co. Ltd, Dorset) was dissolved in dimethylsulphoxide (DMSO) to give a stock concentration of $10^{4} \mu \mathrm{g} / \mathrm{ml}$ and stored at $4^{\circ} \mathrm{C}$. The drug was shown to inhibit phagocytosis by Naegleria trophozoites by suspending amoebae $\left(1.0 \times 10^{5} / \mathrm{ml}\right)$ in ME-cell $\mathrm{MM}$ containing cytochalasin B at concentrations ranging from $1 \mu \mathrm{g} / \mathrm{ml}$ to $10 \mu \mathrm{g} / \mathrm{ml}$ and, after incubation at room temperature for $30 \mathrm{~min}$, adding $0.1 \mathrm{ml}$ of a suspension $(c .0 \cdot 16 \%$, based on packed-cell volume) of day-old-chick erythrocytes in MM. Cytochalasin B-free controls were included and the suspensions were incubated at $37^{\circ} \mathrm{C}$ for up to $24 \mathrm{~h}$. Wet preparations were examined microscopically ( $\times 10$ objective) at appropriate intervals and the proportion of amoebae containing ingested erythrocytes, expressed as a percentage of the total number of trophozoites present in three low-power fields, was noted.

Inhibition of the cytopathogenicity of Naegleria was studied by the inoculation of amoebae that had been treated with $10 \mu \mathrm{g} / \mathrm{ml}\left(2 \cdot 1 \times 10^{-5} \mathrm{M}\right)$ cytochalasin B for $30 \mathrm{~min}$. at room temperature into tube cultures of ME cells to give cytochalasin B and trophozoite concentrations of $10 \mu \mathrm{g} / \mathrm{ml}$ and $5 \times 10^{3} / \mathrm{ml}$ respectively. Uninoculated ME-cell monolayers and cell cultures inoculated with cytochalasin B or amoebae only were used as controls. The medium in all cultures, including controls, contained $0.1 \% \mathrm{DMSO}$, used as the solvent for cytochalasin $\mathrm{B}$. The cultures were incubated at $37^{\circ} \mathrm{C}$ for up to 8 days and examined daily by low-power microscopy.

Colchicine. The above methods were also used to investigate the effect of colchicine (BDH Chemicals Ltd, Poole, Dorset) at concentrations of $10^{-4} \mathrm{M}-10^{-6} \mathrm{M}$ on the phagocytic activity and cytopathogenicity of Naegleria. 


\section{RESULTS}

\section{Inhibition of $N$. fowleri cytopathogenicity by amoeba antiserum}

The cytopathic activity of Naegleria in ME-cell cultures was inhibited by amoeba antiserum (Table I), and the trophozoites were immobilised and

TABLE I

Effect of amoeba antiserum on the cytopathogenicity of Naegleria fowleri strain $H B-1$ in $M E$-cell cultures

\begin{tabular}{|c|c|c|}
\hline$\underset{\text { (dilution) }}{\text { Serum }}$ & $\begin{array}{l}\text { Number of } \\
\text { trophozoites } \\
\text { inoculated }\end{array}$ & $\begin{array}{l}\text { Cytopathic effect } \\
\text { (CPE) in ME-cell } \\
\text { cultures }\end{array}$ \\
\hline $\begin{array}{l}N . \text { fowleri strain } \\
\text { HB-1 antiserum } \\
\quad(1 \text { in } 8)\end{array}$ & $\left\{\begin{array}{c}10^{5} \\
10^{4} \\
0\end{array}\right.$ & $\begin{array}{l}+ \\
- \\
-\end{array}$ \\
\hline $\begin{array}{l}\text { normal rabbit } \\
\text { serum } \\
(1 \text { in } 8)\end{array}$ & $\left\{\begin{array}{c}10^{5} \\
10^{4} \\
0\end{array}\right.$ & $\begin{array}{r}++ \\
++\end{array}$ \\
\hline
\end{tabular}

$+++=$ Complete CPE by lst day after inoculation; $++=$ complete CPE by 3rd day after inoculation; $+=$ complete CPE by 5th day after inoculation; $-=$ no CPE after 7 days.

agglutinated. Clumps of amoebae were seen scattered over intact ME-cell monolayers $24 \mathrm{~h}$ after inoculation (fig. 1a), and individual ME cells immediately beneath the clumps appeared quite normal when the organisms were dislodged by gentle shaking of the culture tubes. After incubation for another $24 \mathrm{~h}$, the initially aggregated organisms in cultures receiving $10^{5}$ trophozoites began to move very slowly in ever-expanding circles, destroying the ME cells as they advanced, to produce clear plaques in the monolayers (fig. 1b). However, complete CPE occurred only after 5 days, whereas the same number of amoebae in the presence of normal rabbit serum caused total destruction of the ME cells within $24 \mathrm{~h}$. In cultures inoculated with $10^{4}$ trophozoites, the amoebae remained agglutinated in the presence of specific antiserum throughout the period of observation, although they continued to show signs of life in the form of spasmodic cytoplasmic eruptions. CPE was not observed in the ME-cell monolayers in the immediate vicinity of the agglutinated organisms.

Effect of cytochalasin B and colchicine on phagocytic and cytopathic activity of Naegleria

The results of preliminary experiments with cytochalasin $B$, in which avian erythrocytes were used as indicators of phagocytosis by amoebae, are presented in table II. In control suspensions, erythrocytes were quickly engulfed by Naegleria trophozoites and numerous ingested red cells were clearly visible within the cytoplasm of the amoebae (fig. 2). By contrast, cytochalasin B at 
TABLE II

Effect of cytochalasin B on the ingestion of day-old chick erythrocytes by trophozoites of Naegleria strain $\mathbf{H B}-1$

\begin{tabular}{|c|c|c|c|c|c|c|}
\hline \multirow{2}{*}{$\begin{array}{l}\text { Time } \\
\text { (hours) } \\
\text { after addition } \\
\text { of erythrocytes }\end{array}$} & \multicolumn{6}{|c|}{$\begin{array}{l}\text { Percentage* of amoebae containing ingested } \\
\text { erythrocytes in the presence of cytochalasin B at } \\
\text { concentrations }(\mu \mathrm{g} / \mathrm{ml}) \text { of }\end{array}$} \\
\hline & 10 & $7 \cdot 5$ & 5 & 2 & 1 & 0 \\
\hline $\begin{array}{r}1 \\
2 \\
3 \\
5 \\
7 \\
24\end{array}$ & $\begin{array}{l}0 \\
0 \\
0 \\
0 \\
0 \\
0\end{array}$ & $\begin{array}{l}0 \\
0 \\
0 \\
0 \\
0 \\
0\end{array}$ & $\begin{array}{r}5 \\
10 \\
5 \\
2 \\
1 \\
0\end{array}$ & $\begin{array}{l}80 \\
90 \\
99 \\
99 \\
90 \\
30\end{array}$ & $\begin{array}{r}95 \\
100 \\
100 \\
100 \\
95 \\
40\end{array}$ & $\begin{array}{r}95 \\
100 \\
100 \\
100 \\
95 \\
40\end{array}$ \\
\hline
\end{tabular}

- Approximate assessment.

concentrations exceeding $5 \mu \mathrm{g} / \mathrm{ml}$ totally inhibited erythrocyte ingestion (fig. 3 ), although the amoebae remained active and continued to show random motility after $24 \mathrm{~h}$.

The use of DMSO as the solvent for cytochalasin B did not influence cell-culture findings. The morphology of control ME cells appeared normal when DMSO alone was incorporated in the culture medium (fig. 4). The cytopathogenicity of Naegleria was also unaffected by DMSO, and ME-cell cultures inoculated with amoebae in the absence of cytochalasin B were completely destroyed within $24 \mathrm{~h}$ (fig. 5). Cytochalasin B itself, however, induced unusual morphological changes in the ME cells, notably the formation of distinctive dendritic processes (fig. 6); the nuclei were often displaced to the periphery of the cells and occasionally were completely extruded. These changes occurred within $24 \mathrm{~h}$ from the addition of cytochalasin B, but progressed no further over the next seven days. If cytochalasin B was removed by changing the medium after the third day, the ME cells gradually resumed their normal morphology.

Fig. 1.-Mouse-embryo (ME) cell culture inoculated with trophozoites of Naegleria strain HB-1 in the presence of amoeba-specific antiserum. (a) $24 \mathrm{~h}$ after inoculation, showing immobilised and agglutinated amoebae. Adjacent ME cells appear undamaged. Phase contrast (PC). $\times 125$. (b) $48 \mathrm{~h}$ later, the trophozoites have resumed motility, and destruction of ME-cells by the expanding circle of amoebae results in the formation of a well-defined plaque in the monolayer. PC. $\times 125$.

Fig. 2.-Trophozoites of Naegleria strain HB-1 $3 \mathrm{~h}$ after the addition of chick erythrocytes (control suspension). The amoebae (arrows) contain numerous ingested red cells. PC. $\times 490$.

Fig. 3.-Trophozoites of Naegleria strain HB-1 $3 \mathrm{~h}$ after suspension in medium containing chick erythrocytes and cytochalasin B $(10 \mu \mathrm{g} / \mathrm{ml})$. Phagocytosis of erythrocytes by amoebae (arrows) is inhibited. PC.

FIG. ${ }^{\times} .490$ Normal (uninoculated) ME-cell culture. The medium contained $0 \cdot 1 \%$ DMSO. PC. $\times 125$.

FIG. 5.-ME-cell culture $24 \mathrm{~h}$ after inoculation with $5 \times 10^{3}$ trophozoites of Naegleria strain HB-1 in the presence of $0 \cdot 1 \%$ DMSO alone. The monolayer is completely destroyed. PC. $\times 125$.

Fig. 6.-ME-cell culture $24 \mathrm{~h}$ after the addition of cytochalasin B $(10 \mu \mathrm{g} / \mathrm{ml})$, showing characteristic morphological changes induced by the drug. PC. $\times 125$.

Fig. 7.-ME-cell culture $24 \mathrm{~h}$ after inoculation with $5 \times 10^{3}$ trophozoites of Naegleria strain HB-1 in the presence of cytochalasin $\mathrm{B}(10 \mu \mathrm{g} / \mathrm{ml})$. The mammalian cells show only those morphological changes associated with cytochalasin B (compare with figs. 5 and 6 ). PC. $\times 125$. 


\section{INHIBItION OF NAEGLERIA CYTOPATHOGENICITY}
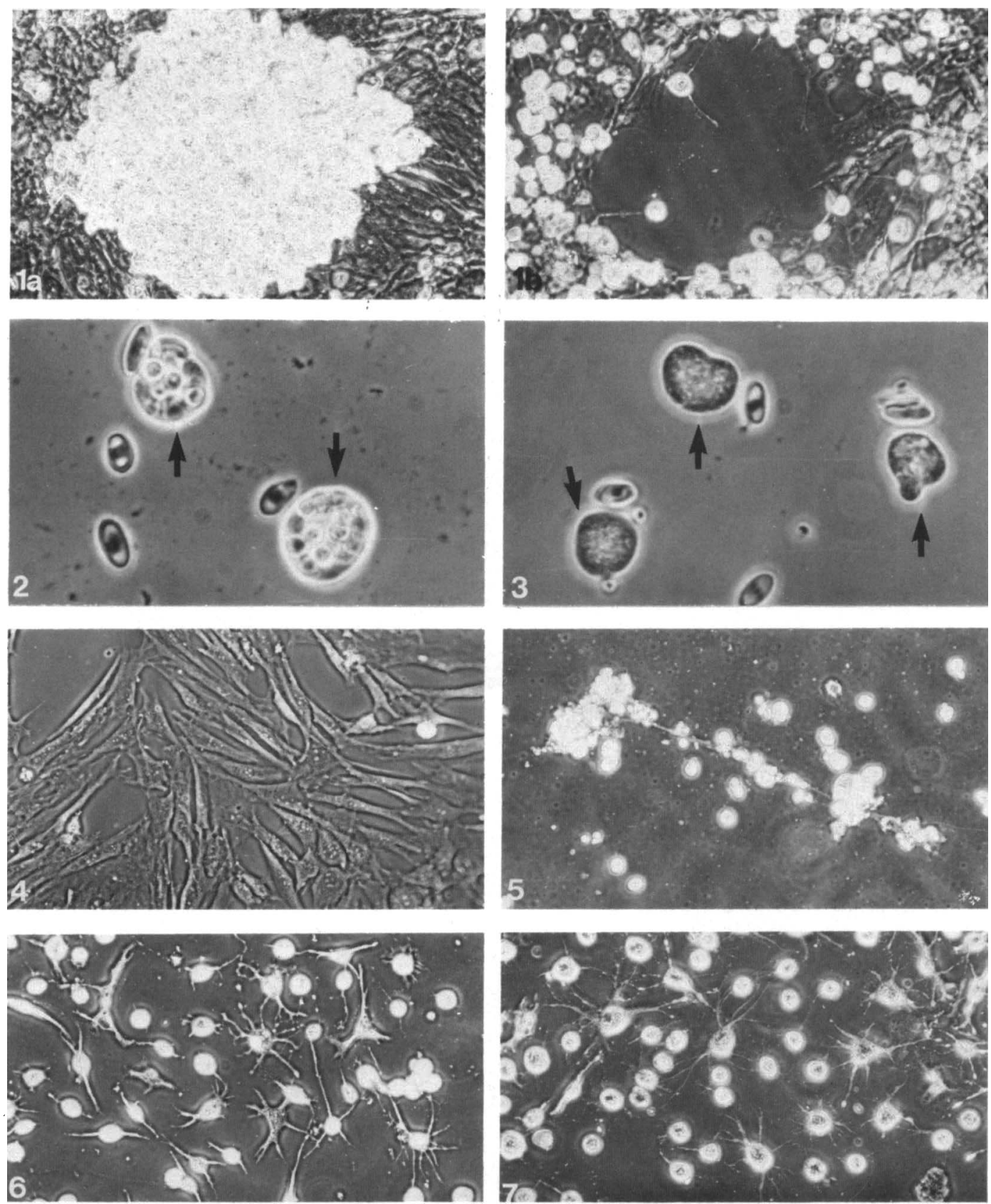
ME cells inoculated with Naegleria trophozoites in the presence of cytochalasin B showed only the morphological changes characteristic of the drug alone (fig. 7). There was no evidence for disruption of mammalian-cell cytoplasm despite repeated contact with amoebae that remained alive and active, although motility was somewhat sluggish and erratic. The organisms contained few cytoplasmic vacuoles and became gradually smaller as incubation continued. By the fifth day, the trophozoites usually were no longer viable, but if the culture medium was changed beforehand they recovered and showed normal cytopathic activity.

Colchicine at concentrations of $10^{-4}-10^{-6} \mathrm{M}$ failed to prevent engulfment of erythrocytes by amoebae. Similar colchicine concentrations in naegleriainfected ME-cell cultures also caused no apparent inhibition of cytopathogenicity; the CPE progressed at the same rate as in colchicine-free control cultures and was complete $24 \mathrm{~h}$ after inoculation.

\section{Discussion}

These results suggest that the cytopathogenicity of $N$. fowleri in ME cells does not involve amoeba-associated cytotoxic activity, but depends on normal pseudopodium function. Trophozoites that were immobilised, and agglutinated, by specific antiserum were unable to cause $\mathrm{CPE}$; no detectable damage of ME cells occurred even in the region of large aggregates of amoebae. As pseudopodia may be formed by amoebae to effect ingestion as well as movement, the antiserum probably inhibited both activities, particularly in cultures inoculated with $10^{4}$ trophozoites, in which the organisms remained immobilised and non-cytopathogenic long after control cultures had been completely destroyed. The slowly progressing CPE in heavily inoculated cultures appeared only when the trophozoites began to recover from the inhibitory effects of the antiserum and presumably resumed phagocytosis in addition to motility. It was not clear how this recovery occurred, but Biagi and Beltrán (1969) have shown that the ability of $E$. histolytica to regain mobility in the presence of specific antiserum is associated with endocytosis and digestion of surface-bound antibodies. The specific immobilisation of Acanthamoeba castellanii may also be a temporary phenomenon (Krantz, 1969).

The total inhibition of naegleria cytopathogenicity in the presence of cytochalasin B was particularly significant. This was not thought to be due to increased resistance of the ME cells, although they were clearly affected by the drug and showed changes in morphology similar to those observed in mouse L-cells by Carter (1967). If, as previously suggested (Brown, 1978), the cytoplasmic processes of fibroblast-like cells are prone to attack by Naegleria trophozoites, the exaggerated protuberances of ME cells induced by cytochalasin B should have been especially susceptible to damage. Instead, the drug appeared to inhibit the cytopathogenicity of Naegleria by influencing trophozoite behaviour. A metabolite of Helminthosporium dematioideum (Carter, 1967), cytochalasin B, is known to induce a wide range of dose-dependent changes in cellular-transport and motility processes (Wessells et al., 1971; 
Pollard and Weihing, 1974). At relatively high concentrations $\left(c .10^{-5} \mathrm{M}\right)$, the drug inhibits phagocytosis by mammalian macrophages and polymorphonuclear leucocytes, possibly by disrupting contractile microfilament systems (Allison, Davies and de Petris, 1971; Axline and Reaven, 1972; Davies et al., 1973; Hartwig and Stossel, 1976; Weihing, 1976). That cytochalasin B also prevents phagocytosis by Naegleria trophozoites was demonstrated during the present studies by the inability of treated amoebae to engulf chick erythrocytes. By implication, the failure of amoebae to cause CPE in ME-cell cultures in the presence of cytochalasin B was likewise associated with the suppression of the feeding activity of trophozoites. Certainly, the amoebae showed signs of starvation, including lack of cytoplasmic vacuoles, gradually decreasing size and failure to thrive, while the random, uncoordinated motion of the organisms was consistent with pseudopodium dysfunction. On the other hand, the inability of colchicine to prevent ingestion of erythrocytes and destruction of ME-cells by Naegleria trophozoites was not entirely unexpected. Although colchicine disrupts microtubules (Novikoff and Holtzman, 1970) which, with microfilaments, may participate in cell movement and possibly endocytosis (Allison et al., 1971; Reaven and Axline, 1973), phagocytosis by macrophages has been shown to proceed normally in the presence of the drug (Allison et al., 1971; Bhisey and Freed, 1971).

A notable feature of these studies was the inhibition of naegleria cytopathogenicity by two quite different agents without directly affecting the viability of the organisms. Trophozoites in the presence of specific antiserum or cytochala$\sin B$ were no longer cytopathogenic, though still alive and in constant contact with the ME cells. In these circumstances, there was no evidence for any cytotoxic mechanism of mammalian-cell damage by the amoebae. It is possible, of course, that the immunological and chemical inhibitors of trophozoite movement and phagocytosis also blocked the release or action of amoebaassociated cytotoxins. However, the demonstrable association between trophozoite feeding activity and cytopathogenicity, seen particularly in studies with cytochalasin B, is in keeping with previous observations (Brown, 1978) and suggests that the amoebae destroy cultured mammalian cells by phagocytosis alone.

\section{SUMMARY}

Inhibitors of trophozoite motility and phagocytosis were used to investigate the mechanism of Naegleria fowleri cytopathogenicity in mouse-embryo (ME)cell cultures. Amoebae that were immobilised and agglutinated by specific antiserum exhibited no cytopathic activity, although they remained alive and were in constant contact with the ME cells. Mammalian-cell damage occurred only when the organisms recovered pseudopodium function and began to migrate over the monolayers as they overcame the inhibitory effects of the antiserum. Cytochalasin B at a concentration of $10 \mu \mathrm{g} / \mathrm{ml}$, shown to prevent the engulfment of chick erythrocytes by amoebae, also inhibited the cytopathogenicity of Naegleria when incorporated in ME-cell culture medium. Despite 
repeated contact with active trophozoites, the ME cells showed only those morphological changes characteristically induced by cytochalasin B itself. The amoebae in turn showed signs of starvation after 3 or 4 days' incubation, suggesting that the feeding activity of trophozoites was suppressed. Colchicine, on the other hand, inhibited neither the ingestion of erythrocytes nor the destruction of ME cells by amoebae. It was concluded that the cytopathogenicity of $N$. fowleri in ME-cell cultures was due to physical rather than biochemical or cytotoxic mechanisms and was associated with the phagocytic activity of trophozoites.

\section{REFERENCES}

Allison, A. C., Davies, P. And de Petris, S. 1971. Role of contractile microfilaments in macrophage movement and endocytosis. Nature, New Biol., 232, 153.

ANDERSON, K. AND JAmieson, A. 1972. Agglutination test for the investigation of the genus Naegleria. Pathology, Sydney, 4, 273.

AXLINE, S. G. AND REAVEN, E. 1972. In vitro inhibition of phagocytosis and disruption of microfilaments by cytochalasin B. J. clin. Invest., 51, 6a.

BHISEY, A. N. AND FREED, J. J. 1971. Altered movement of endosomes in colchicine-treated cultured macrophages. Expl Cell Res., 64, 430.

BiAGI, F. F. AND BeLTRÁN, H. F. 1969. The challenge of amebiasis: understanding pathogenic mechanisms. Int. Rev. trop. Med., 3, 219.

Brown, T. 1978. Observations by light microscopy on the cytopathogenicity of Naegleria fowleri in mouse embryo-cell cultures. J. med. Microbiol., 11, 249.

CARTER, R. F. 1968. Primary amoebic meningo-encephalitis: clinical, pathological and epidemiological features of six fatal cases. J. Path. Bact., 96, 1.

CARTER, R. F. 1970. Description of a Naegleria sp. isolated from two cases of primary amoebic meningo-encephalitis and of the experimental pathological changes induced by it. J. Path., $100,217$.

CARTER, R. F. 1972. Primary amoebic meningo-encephalitis. An appraisal of present knowledge. Trans. R. Soc. trop. Med. Hyg., 66, 193.

CARTER, S. B. 1967. Effects of cytochalasins on mammalian cells. Nature, Lond., 213, 261.

CHANG, S. L. 1973. Pathogenic free-living amoebae and recreational waters. In Advances in water pollution research, edited by S. H. Jenkins, Oxford, p. 85 .

Culbertson, C. G. 1971. The pathogenicity of soil amebas. A. Rev. Microbiol. 25, 231.

Davies, P., Fox, R. I., Pol yzonis, M., Allison, A. C. AND Haswell, A. D. 1973. The inhibition of phagocytosis and facilitation of exocytosis in rabbit polymorphonuclear leukocytes by cytochalasin B. Lab. Invest., 28, 16.

Duma, R. J. 1972. Primary amoebic meningoencephalitis. C.R.C. Crit. Rev. clin. lab. Sci., 3, 163.

Eaton, R. D. P., Meerovitch, E. ANd Costerton, J. W. 1969. A surface-active lysosome in Entamoeba histolytica. Trans. R. Soc. trop. Med. Hyg., 63, 678.

Eaton, R. D. P., MeErovitch, E. AND Costerton, J. W. 1970. The functional morphology of pathogenicity in Entamoeba histolytica. Ann. trop. med. Parasit., 64, 299.

HARTWIG, J. H. AND Stossell, T. P. 1976. Interactions of actin, myosin, and an actin-binding protein of rabbit pulmonary macrophages. III. Effects of cytochalasin B. J. cell Biol., 71, 295.

Jarumilinta, R. AND Kradolfer, F. 1964. The toxic effect of Entamoeba histolytica on leukocytes. Ann. trop. med. Parasit., 58, 375.

KranTZ, G. E. 1969. Acanthamoeba castellanii: specificity of immobilization test. Expl. Parasit., 26, 299.

Maitra, S. C., Krishna Prasad, B. N., Das, S. R. and Agarwala, S. C. 1974. Study of Naegleria aerobia by electron microscopy. Trans. R. Soc. trop. Med. Hyg., 68, 56.

Maitra, S. C., Krishna Prasad, B. N., Agarwala, S. C. and Das, S. R. 1976. Ultrastructural 
studies on experimental primary amoebic meningo-encephalitis (PAME) of mouse due to Naegleria aerobia and Hartmannella culbertsoni. Int. J. Parasit. 6, 489.

Martinez, A. J., Duma, R. J., Nelson, E. C. AND MoretTA, F. L. 1973. Experimental naegleria meningoencephalitis in mice. Penetration of the olfactory mucosal epithelium by naegleria and pathological changes produced: a light and electron microscope study. Lab. Invest., 29, 121.

Newton, B. A. 1972. Protozoal pathogenicity. In Microbial pathogenicity in man and animals, symposium no. 22, Society for General Microbiology, edited by H. Smith and J. H. Pearce, Cambridge, p. 269.

Novikoff, A. B. And Holtzman, E. 1970. Cells and organelles, New York, pp. 150, 152.

PAGE, F. C. 1967. Taxonomic criteria for limax amoebae, with descriptions of 3 new species of Hartmannella and 3 of Vahlkampfia. J. Protozool., 14, 499.

PhilliPs, B. P. 1974. Naegleria: another pathogenic ameba. Studies in germfree guinea pigs. Am. J. trop. Med. Hyg., 23, 850.

Pollard, T. D. AND WeIHING, R. R. 1974. Actin and myosin and cell movement. C.R.C. crit. Rev. Biochem., $2,1$.

ReAven, E. P. AND AXuine, S. G. 1973. Subplasmalemmal microfilaments and microtubules in resting and phagocytizing cultivated macrophages. J. cell. Biol. 59, 12.

SINGH, B. N. AND DAS, S. R. 1970. Studies on pathogenic and non-pathogenic small free-living amoebae and the bearing of nuclear division on the classification of the order Amoebida. Phil. Trans. R. Soc. B., 259, 435.

Visvesvara, G. S. AND Callaway, C. S. 1974. Light and electron microscopic observations on the pathogenesis of Naegleria fowleri in mouse brain and tissue culture. J. Protozool., 21, 239.

Weiring, R. R. 1976. Cytochalasin B inhibits actin-related gelation of HeLa cell extracts. J. cell Biol., 71, 303.

Wessells, N. K., Spooner, B. S., Ash, J. F., Bradley, M. O., Luduena, M. A., Taylor, E. L., WRENN, J. T. AND YAMADA, K. M. 1971. Microfilaments in cellular and developmental processes. Science, N.Y., 171, 135. 